Article

\title{
Policy Integration and Multi-Level Governance: Dealing with the Vertical Dimension of Policy Mix Designs
}

\author{
Michael Howlett ${ }^{1, *}$, Joanna Vince ${ }^{2}$ and Pablo del Río ${ }^{3}$ \\ ${ }^{1}$ Department of Political Science, Simon Fraser University, Burnaby, BC V5A 1S6, Canada; E-Mail: howlett@sfu.ca \\ 2 School of Social Sciences, University of Tasmania, Hobart, 7250, Australia; E-Mail: Joanna.vince@utas.edu.au \\ 3 Spanish National Research Council, 28006 Madrid, Spain; E-Mail: pablo.delrio@csic.es \\ * Corresponding author
}

Submitted: 25 February 2017 | Accepted: 12 April 2017 | Published: 5 May 2017

\begin{abstract}
Multifaceted problems such as sustainable development typically involve complex arrangements of institutions and instruments and the subject of how best to design and operate such 'mixes', 'bundles' or 'portfolios' of policy tools is an ongoing issue in this area. One aspect of this question is that some mixes are more difficult to design and operate than others. The paper argues that, ceteris paribus, complex policy-making faces substantial risks of failure when horizontal or vertical dimensions of policy-making are not well integrated. The paper outlines a model of policy mix types which highlights the design problems associated with more complex arrangements and presents two case studies of similarly structured mixes in the areas of marine parks in Australia and coastal zone management in Europe-one a failure and the other a successful case of integration - to illustrate how such mixes can be better designed and managed more effectively.
\end{abstract}

\section{Keywords}

marine parks; governance; policy integration; policy mixes

\section{Issue}

This article is part of a multidisciplinary issue of Politics and Governance, edited by Andrej J. Zwitter (University of Groningen, The Netherlands) and Amelia Hadfield (Canterbury Christ Church University, UK).

(C) 2017 by the authors; licensee Cogitatio (Lisbon, Portugal). This article is licensed under a Creative Commons Attribution 4.0 International License (CC BY).

\section{Introduction: The Issue of Optimality in Complex Policy Portfolios}

The complexity of contemporary socio-economic and environmental problems and the requirements of planning for the needs of client groups and affected regions are problems which challenge policy-makers on many levels (Levin, Cashore, Bernstein, \& Auld, 2012). Protecting components of, and entire, eco-systems under conditions of global warming, for example, increasingly involves the development and implementation of arrangements of policy goals and instruments in 'policy mixes' (Kern \& Howlett, 2009), and how best to design such mixes is an ongoing issue in the policy sciences.

After several decades of policy-making experience and research in many countries, it is evident that sector- alized, uni-dimensional, and uncoordinated policies do not serve well the cause of many complex policy problems, such as sustainable development or dealing with hunger or homelessness (Cejudo \& Michel, 2017). While many studies have noted these issues and the need for a more integrated approach to policy-making in such areas (Briassoulis, 2014; Jordan \& Lenschow, 2008, 2010), how exactly policies are to be better integrated remains unclear (Candel, Jeroen, \& Biesbroek, 2016).

As this paper argues, answering this question requires, among other things, a better understanding of the nature of policy mixes than presently exists in the literature. This subject has been the central concern of recent works delving into the examination of 'packages'; 'bundles' or 'portfolios' of policy tools in the policy sciences (Chapman, 2003; Doremus, 2003; Hennicke, 2004; 
Milkman, 2012) and bringing the insights of this literature to bear on policy design in complex problem areas is the aim of this paper.

The discussion below sets out a model of policy mixes focusing on the nature of the tools required to address complex policy problems in order to better define what integration means in such contexts. It then examines the history of efforts to promote integrated policy mixes in two environmental issue areas with severe co-ordination problems-coastal zone management (ICZM) in Europe and marine park management in Australia. The first effort was a failure and the second a success, allowing lessons to be derived from these cases about how to design and manage integrated tool packages.

\section{Policy Mixes and Their Vicissitudes}

Most policy areas involve the development and operation of mixes of policy tools and aims. At their most basic, policy mixes can be thought of as bundles of individual policy instruments or tools and techniques used by government in order to achieve their policy goals (Howlett, 2005).

Some problem areas are more complex than others, however, and result in more complex policy mixes. Environmental policies, for example, commonly combine market and regulation-based instruments and include combinations of tools such as regulations on discharges and chemical use, mechanisms for assessing fees or taxes on environmental degradation, tradable permits which establish overall levels of pollution and allocate them among firms. Market friction reduction efforts such as enactment of liability rules designed to encourage firms to consider the potential environmental damages of their decisions, information programs such as product labelling requirements and reporting requirements, and government subsidy reductions which attempt to reduce the inefficient behaviour promoted by many government subsidy programs (Anderson et al., 2010). They often also involve user charges intended to promote compliance with first and second equimarginality rules (Tietenberg \& Lewis, 2008) and lead firms to reduce emissions to the point where the marginal abatement cost equals the tax rate.

There are always significant interactive effects among the policy goals, sectors and governments involved which also add to the complexity of policy design and the difficulties encountered in pursuing effective integration (Boonekamp, 2006; Del Río, 2010; Grabosky, 1995; LePlay \& Thoyer, 2011; Yi \& Feiock, 2012). This is because in many circumstances 'supplementary' or 'complimentary' tools are often required to control sideeffects or otherwise bolster the use of more 'primary' tools (Hou \& Brewer, 2010; Tinbergen, 1952).

And there is also a temporal dimension to complexity as, in many cases, tools and instruments from one era have been 'layered' on top of others in an often less than rational process of matching overall pol- icy means with goals, resulting in inconsistencies and incongruencies in tools embedded in such arrangements (Howlett \& Mukherjee, 2014; Howlett \& Rayner, 2004). And this complexity is augmented even further when tool choices and preferred combinations of instruments deal with ideological or even 'aesthetic' preferences in tool choices and goal articulation rather than issues around efficiency or equity, and when they involve trade-offs and bargaining between actors in choosing types of tools, goals and policies (Beland \& Wadden, 2012; Williams \& Balaz, 1999).

The existing evidence shows that for all these reasons, suboptimal situations in which duplication and unnecessary redundancies and gaps remain in existing policy mixes are very common. And this is more likely to occur in complex problem areas with many actors and affected parties involved in mixes which have developed over lengthy periods of time, a situation which again is not exceptional in policy-making but rather quite common.

The nature of such mixes focuses attention on issues related to their development and alteration over time, such as exactly how the sequencing of instrument choices occurs and how negative policy legacies can be overcome (Taeihagh, Givoni, \& Bañares-Alcántara, 2013). Despite the difficulties involved in identifying the elements of such mixes and how they emerge, as the case studies presented below illustrate, understanding the nature of the existing mix and its evolution aids understanding of how it can be altered to help improve policy outputs and outcomes.

\section{Enhancing Integration as Enhancing Complementarity and Minimizing Inconsistency among Policy Instruments}

The issue of the nature of the design of 'optimal' bundles of tools in policy mixes has only recently begun to be addressed by policy scholars (Howlett, 2005; Peters, 2005). Most existing literature on policy tools and goals to date, rather, has focused on single instrument choices and less complex designs (Salamon, 1989; Trebilcock \& Prichard, 1983; Tupper \& Doern, 1981). Such studies, unfortunately, provide only limited insight into how to design and operate more complex, but quite common, 'portfolios' of tools (Jordan, Benson, Wurzel, \& Zito, 2011; Jordan, Benson, Zito, \& Wurzel, 2012).

Integration-understood as the smooth coexistence of the different elements of policy, including goals, policies and government levels involved in policy mix design and creation, so that conflicts are minimized and, if possible, synergies and complementarities are promotedhas been identified repeatedly as a key feature of wellperforming mixes (Briassoulis, 2004; Howlett, 2004).

One major issue identified in the design and operation of any mix linked to poor integration, for example, is that the tools involved and invoked in a mix may be inherently contradictory (Gunningham, Grabosky, \& Sinclair, 
1998; Tinbergen, 1952). That is, they may evoke contradictory responses from policy targets, cancelling out or confusing their effects (Schneider \& Ingram, 1990, 1993, $1994,1997,2005)$ such as occurs, for example, when a subsidy is provided to encourage certain kinds of production while that production is simultaneously discouraged through various forms of regulation (Grabosky, 1995). The potential for such contradictory relationships to exist increases as the number of tools in a mix increases and steps should be taken to identify and reduce their number if better integration is to occur.

Similarly, other combinations of tools may be more virtuous in providing a reinforcing or supplementing arrangement (Hou \& Brewer, 2010). And some arrangements may be unnecessarily duplicative while in others some redundancy may be advantageous (Braathen, 2005,2007 ) as occurs for instance in the provision of multiple programmes to help offset poverty or illness. Again, better integration involves promoting as many positive relationships as possible within a mix.

Avoiding ill-effects and bolstering positive interactions within portfolios and thereby promote better integration is thus a central aim and concern of policymakers. But achieving this higher level of integration is not a simple thing to accomplish. In the case of ecosystem services, for example, co-ordination problems are omnipresent. One such challenge there concerns properly identifying the appropriate tax rate or user charge to be used. Ideally this should be set equal to the marginal benefits of environmental preservation at an efficient level of preservation. However, there is likely to be uncertainty among policy-makers as to how firms will respond to a given level of taxation and about what is the most efficient level of preservation. Tradable permits allow firms which keep below their allotted level to sell their surplus permits or use them to offset excess emissions in other parts of their operations. Their use, however, raises other issues such as how to properly allocate permits between techniques such as auctioning, grandfathering or benchmarking, among other possibilities. Moreover, there are additional issues associated with the possible joint effects of user charges and tradeable permits as well as the other components of an ecosystem services mix which must be taken into account if efforts in this area are to be effective.

These integration issues become even more complex when the political economy of policy-making is taken into account. That is, certain groups of actors may promote certain options without regard for their impact on other elements of a mix-for example when forest companies advocate for greater cut allotments without tak- ing into account their impact on fisheries or endangered species-and when historical problems of policy legacies exist in a sector (Kiss, Manchón, \& Neij, 2012). Older programmes and policies which have conferred benefits on certain actors, for example, can make it very costly to shift to other arrangements (Anderson et al., 2010) and many existing mixes have developed haphazardly through processes of policy layering, in which new tools and objectives have been piled on top of older ones, creating a palimpsest-like mixture of inconsistent and incoherent policy elements (Carter, 2012; Thelen, 2004; van der Heijden, 2011). Factors such as increasing efforts to promote collaborative or horizontal governance arrangements also affect the number of multi-sectoral and multipolicy situations which exist (Peters, 1998) and raise the issue of policy integration to the forefront of policy design considerations.

\subsection{Enhancing Integration in Instrument Mixes: Understanding Verticality and Horizontality}

The argument presented here is that the first step in addressing and improving policy integration in any policy mix involves accurately diagnosing its level of complexity.

As Table 1 shows, several distinct mix types exist based on the number of goals, the number of policies and the number of levels of government involved in the construction and maintenance of a policy 'portfolio' or 'bundle' (Howlett \& del Río, 2015).

The first two situations can be thought of as 'horizontal' ones which occur within the same level of government, for example, at the level of a single national, international, state or local government. The third situation, however, adds an additional 'vertical' complication, highlighting the manner in which the elements of a mix also have to be co-ordinated across levels of government.

The degree of complexity and the need for, and difficulty in achieving integration grows with the increase in the number of goals, policies and levels of government involved; that is, as the degree of horizontality and verticality increases. 'Horizontal' design considerations increase as the number of problems or issues to be addressed increased. Determining the efficiency of price-based (tax) environmental systems compared with quantity-based (tradable permit) systems, for example, is clear when cost curves are rather flat; then quantity instruments are superior to price instruments. But in many cases the relative shape of the benefit and cost functions of abatement may be unknown (Weitzman, 1974). Also, the longterm cost-effectiveness of taxes versus tradable permits is affected by the relative responses of targets to market-

Table 1. Spectrum of tool mix complexity.

\begin{tabular}{llll}
\hline Simple & & Complex \\
\hline $\begin{array}{l}\text { Single Goals, Policies and } \\
\text { Levels }\end{array}$ & $\begin{array}{l}\text { Single Goals in Multiple } \\
\text { Policies or Levels }\end{array}$ & $\begin{array}{l}\text { Multiple Goals in Multiple } \\
\text { Policies or Levels }\end{array}$ & Multiple Goals in Multiple \\
\hline
\end{tabular}


based tools in terms of effects on aggregate emissions and permit prices. These outputs are affected by factors such as economic growth, inflation, or exogenous technical change but are linked primarily to the number and type of actors and targets involved (Anderson et al., 2010).

These horizontal issues are serious ones in and of themselves but integration is made even more complex and difficult by the existence of any kind of 'verticality' or the involvement of policy actors and elements at different levels of government. That is, in addition to the issues raised above concerning the kinds of contradictory or complementary relationships existing between tools within a single level of policy-making (Hosseus \& Pal, 1997) when a second, 'vertical' dimension is present the level of complexity and the integration challenge increases exponentially. The administrative and legislative arrangements present in federal and non-federal systems, for example, greatly enhance the number of multi-governmental mixes which exist in such jurisdictions (Bolleyer \& Borzel, 2010; Howlett, 1999) as do spatial and other issues which allow policy problems to cross jurisdictional boundaries, as is very common in environmental policy, for example, but also in others such as refugee flows or international trade and industrial activity.

These latter multi-policy, multi-goal and multiinstrument mixes-what Milkman (2012) calls 'policy bundles'-are examples of policy portfolios which are typically much more complex than single or multiple instrument mixes (Chapman, 2003; del Río, 2014; Hennicke, 2004; Howlett \& del Río, 2015) and pose the greatest integration challenges. They typically involve more than simple functional logics linking deployment of a single policy tool such as regulation or tax incentives to accomplishment of a single policy goal and require additional efforts to integrate their various parts which simpler mixes or single instrument choices typically do not.

Conflicts with respect to goals and instruments are likely to be more common and prominent when multiple jurisdictions are involved. This is so because in such multilevel government and governance contexts (Hooghe \& Marks, 2003), different levels of government are likely to have some common, but also different goals and instrument preferences (Enderlein, Wälti, \& Zürn, 2011). These mixes have rarely been studied from a policy integration perspective and the two cases studies presented below illustrate the kinds of mechanisms which have been used, both successfully and unsuccessfully, in two of these efforts. As the cases show, reconciling the components of complex mixes involves not just efforts at better horizontal integration but also the use of an overt political calculus of intra- or intergovernmental bargaining and decision-making and the presence or absence of effective multi-level governance arrangements is a significant factor affecting integration (Bolleyer \& Borzel, 2010; Kaiser, Kaiser, \& Biela, 2012).

\section{Two Case Studies of Policy Mix Design: Learning from the Integration Experience of ICZM in Europe and The Great Barrier Reef in Australia}

Given the trans-boundary nature of many environmental issues, it is common in the environmental sphere for several levels of government to be involved in policymaking processes, including the supranational, national, regional and local, and such issue areas provide good illustrations of the difficulties, and solutions, involved in integrating such complex mixes (del Río, 2009; Howlett \& del Río, 2015). This makes the study of such cases a good one for comparative analysis of the (in)effectiveness of efforts to enhance vertical policy integration in complex policy mixes.

The two cases set out below-efforts to implement Integrated Coastal Zone Management (ICZM) in Europe as well as efforts in Australia to manage Marine Protected Areas-illustrate how mixes of this type face additional risks of failure due to lack of integration across levels of government and policy elements. The cases show these are difficult, but not impossible, to correct (Howlett, Ramesh, \& Wu, 2015; Keast, Brown, \& Mandell, 2007).

The first case can be considered a failure and the second a success as far as integration is concerned. Why this was the case and what lessons can be learned from these experiences are set out below.

\subsection{ICZM in the European Union}

ICZM has been a favoured planning tool of the international development community for many years. Better vertical integration of environmental policy and management efforts has been a major goal of the pursuit of sustainability by the UNCED (1992) and other efforts such as the World Summit on Sustainable Development which passed the Johannesburg Plan of Action in 2002.

ICZM figured prominently in the United Nations Food and Agriculture Organization (FAO) Code of Conduct for Responsible Fisheries (FAO, 1995; Humphreys \& Burbridge, 2003), and Agenda 21 pushed ICZM forward by emphasizing a general commitment on the part of nations to pursue integrated management of coastal areas and the marine environment. This occurred together with a specific call for the development of multilateral ICZM frameworks and guidelines.

Although the OECD was also actively promoting ICZM at this time, the World Bank took the lead and their Guidelines were adopted at the 1993 World Coast Conference in Noordwijk, Holland. UNEP's guidelines for ICZM in the Regional Seas Program also stressed the importance of strengthening cross-sectoral management for successful policy integration. While various guidelines and protocols exist in different regions (for instance in the Mediterranean-the ICZM Protocol to Barcelona Convention for the Mediterranean Sea passed in 2010; IUCN ICZM Protocol in the Mediterranean from 2011), as 
the ICZM name suggests, these guidelines all advocate enhanced horizontal and vertical integration and coordination (Harvey \& Hilton, 2006; Humphrey \& Burbridge, 2003; Portman, Dalton, \& Wiggin, 2015). They include a focus on intersectoral coordination rather than traditional sector-by-sector management; holistic, multidisciplinary ecosystem-based planning; a dynamic, continuous, evolutionary and iterative attempt to solve complex problems; and the creation of new governance structures to accommodate meaningful stakeholder participation and conflict resolution (Post \& Lundin, 1996).

Attaining these goals has not been easy, however. In Europe, ICZM began largely at the project level and of nineteen European countries expected to follow an EU Recommendation on ICZM which called for the development of a national strategy by 2006 , only nine complied. A 1999 study of EU coastal states plus Norway, for example, found a very uneven pattern of ICZM implementation (Table 2); distinguishing between plans that were fully implemented, those merely formulated, and those under development in the pre-formulation stage.

Of 182 coastal regions studied, 108 were recorded as showing no progress in ICZM at all, and only Denmark and the Netherlands had all coastal regions showing at least some progress towards fully formulated or implemented strategies (Elburg-Velinova et al., 1999).

Thus, despite these good intentions in oceans and coastal governance, the implementation of large scale integrated approaches failed to achieve the broad aim of moving beyond the sector-based management of ocean resources that integrated approaches were meant to resolve (Jay et al., 2013; Portman et al., 2015; Vince, 2013, 2014, 2015). Overall, Humphreys and Burbridge (2003) characterized European ICZM as emerging in rather isolated pockets as a response to local situations, in the absence of or without connection to institutional arrangements at more central levels of government.

This illustrates the difficulties involved in creating better integrated policy mixes where multi-level or vertical complications proliferate. Among other things this outcome highlights the importance of understanding the vertical dimension of policy mix design and securing intergovernmental agreement as a pre-condition for moving forward in policy mix design and implementation.

That is, this situation might have been addressed by a Europeanization initiative where the European Commission bypasses national governments and joined up the dots to create a European-wide ICZM policy. Instead, however, the debate over ICZM featured a confrontation between European Parliament and the Council, with the emergence of many national sectoral interests opposed to what they saw as unnecessary disturbance of existing local arrangements.

The ultimate outcome was only a Recommendation on ICZM (2002/413/EC) rather than the Directive that many in the Parliament and the NGO community were originally seeking (McKenna, n.d.). Although coordination was expected to be carried out by an ambitious benchmarking scheme to identify leaders and laggards, the scheme was not put in place in part because of continuing disagreement over what is to be measured. ${ }^{1}$

\subsection{Australia's Great Barrier Reef Marine Park}

The experience of policy-making in a second case of multi-level policy-making involving the Australia's Great Barrier Reef Marine Park, however, was quite different as the central government was able to resolve many intergovernmental issues and retain control and direction over the policy. This case exemplifies the difficulties with integrated policy implementation over four decades but provides useful lessons about how governance arrangements can help overcome integration problems.

The Park was established through the Great Barrier Reef Marine Park Act (Commonwealth) 1975 which defined the Great Barrier Reef Region (also Australia's largest World Heritage Area which was listed in 1981) which extends from the low water mark, an area that

Table 2. State of ICZM in European Coastal Regions, 1999. Source: Elburg-Velinova, Valverde and Salman (1999, p. 15).

\begin{tabular}{lll}
\hline Countries with at least one coastal region where ICZM was & Fully Implemented \\
\hline Under Development & Formulated & Netherlands \\
\hline Belgium & France & United Kingdom \\
Denmark & Greece & \\
Finland & Italy & \\
Germany & & \\
Ireland & & \\
Norway & & \\
Poland & & \\
Spain & & \\
Sweden & & \\
\hline
\end{tabular}

\footnotetext{
1 Thus, a survey of the achievements and intentions of nineteen European countries with respect to the Recommendation on ICZM, showed only nine even intended to develop a national strategy by 2006 , the target date set in the Recommendation, six did not intend to meet this deadline and four did not report their intentions (Janssen, 2004).
} 
is otherwise state jurisdiction in Australia's coastal zone, as part of this arrangement. The Park is managed utilising ecologically sustainably-based principles, a zoning plan that includes multiple use areas and 'provides protection of biodiversity values through a network of notake zones for 33 per cent of its area and for at least 20 per cent of every bioregion' (Commonwealth of Australia, 2013, pp. 5, 11). ${ }^{2}$ The Australian Federal government used the Act, along with its international ratified agreements and external affairs powers, to halt attempts by the Queensland government to begin offshore oil and gas exploration in the reef (Haward \& Vince, 2008, p. 91).

The integration efforts made in this case were more effective and serve as an example of successful multilevel governance, multiple use management, marine spatial planning and integration between jurisdictions, sectors and communities (see Kenchington \& Day, 2011); overcoming the challenges with vertical and horizontal integration posed to achieve biodiversity conservation in the face of complex political conflicts. The results from the integrated management efforts made by governments in the case of Australia's Great Barrier Reef Marine Park (GBRMP) highlight the point made in the ICZM case above concerning the need to early recognize and act on the appropriate dimension(s)-horizontal or vertical or both-of a mix if better integration is to be achieved, often involving the exercize of some central control over local issues and concerns.

This can be seen in the activities undertaken around the turn of the millennium when the GBRMP was rezoned in 2004 to provide better environmental protection by increasing the size of fishing no-take zones. This exercise was met with opposition from the recreational and commercial fishing groups who found the process inequitable (Sutton \& Tobin, 2009, p. 250). Surveys found recreational fishers had low to moderate satisfaction with the programme used to consult the public throughout the rezoning process', were more likely to be supportive of the changes if consistent with their values, and believed that the outcomes of the process were 'predetermined' (Sutton \& Tobin, 2009).

Lack of communication, policy coordination and cooperation between decision makers, agencies, key actors and those affected by the policy (Briassoulis, 2004, p. 20) were also recognized by the governing bodies as potentially resulting in unfavourable outcomes and efforts were taken to ameliorate them. The federal government spent five years and AUS\$200 million assisting affected parties adjusting to the new arrangements (Fernandes et al., 2005; Macintosh, Bonyhady, \& Wilkinson, 2010).

Fernandes et al. (2005, p. 1742) argue that without this financial assistance, community acceptance of the new zoning arrangements would have been difficult to achieve. However the key vertical integrative device employed in this case was the creation of an Authority which liaises and coordinates policies with other Federal and Queensland government agencies within the framework outlined in the Great Barrier Reef Intergovernmental Agreement (2009) (updated in 2015). The aim of the Authority was to enhance environmental protection of the reef, economic development and community participation while minimising regulation (Sainsbury, Haward, Kriwoken, Tsamenyi, \& Ward, 1997, p. 27). It jointly manages vertical coordination and decision making within the region through different management tools including Fishery Management Plans, Cruise Shipping Policy for the Great Barrier Reef Marine Park, Traditional Use of Marine Resource Agreements, and Environmental Impact Management policies (Day \& Dobbs, 2013, p. 17; GBRMP, 2014).

In addition to specific plans, planning authorities and financing for enhancing inter-governmental coordination, special efforts were also made in this case by the Authority to enhance public participation opportunities and to develop vehicles intended to address concerns raised in policy development processes. This is well illustrated in the GBRMP rezoning process which took six years to complete due to a complex community consultation process (Fernandes et al., 2005, p. 1738) but which, in the end, was completed successfully only through the cooperation of non-state or private actors, such as the Indigenous community, environmental NGOs and the local tourism industry.

\section{Conclusions}

Attaining better policy integration involves adopting policy tools capable of overcoming or avoiding conflicts and contradictions in a policy mix. This is an important aspect of policy-making and policy design which is made difficult to achieve in the ever more common practice of the bundling of policy tools together into complex arrangements in order to address complex multi-faceted and multi-level policy problems.

The emergence of more, and more complex, mixes raises many difficult questions regarding how best to integrate policy elements developed over time through a range of processes from special pleading on the part of affected interests to historical lock-in caused by the layering of one policy element on top of another.

Understanding how such mixes operate, what are their strengths and weaknesses and how their problems can be overcome are significant subjects of interest in the policy sciences. Existing studies of integration, however, do not use a consistent terminology and often fail to define the dependent variable carefully enough to have been able to make much headway in addressing many aspects of tool mix design. As a result, the cumulative impact of empirical studies has not been great, theorization has lagged, and the understanding of integration has not improved as much as it should have over past decades (Chapman, 2003; Ring \& Schroter-

\footnotetext{
2 The GBRMP has just undergone another bleaching event and is now being reviewed again for being listed as 'in danger' if not removed completely off the UNESCO world heritage listing. This will no doubt intensify planning activities undertaken by the Board in the near future.
} 
Schlaack, 2010), undermining efforts to promote better policy-making, policies and outcomes.

Design principles to promote integration in complex mixes featuring high levels of verticality especially require a broader view of the elements found in policy mixes than is typically found in the literature on the subject (da Costa Canoquena, 2013; del Río, 2009). To help resolve this issue, the article developed a framework for analyzing integration utilizing the twin dimensions of horizontality and verticality, noting the increased complexity which occurs in cases where not only are issues of policy design centered on how best to deal with instrument interactions in a single policy area or level of government but where they span two or more such levels. The paper argues this 'vertical' or multilevel dimension of more complex mixes has not been taken into account enough in past work and that this dimension has to be added to the more commonly acknowledged 'horizontal' one in order to properly understand the functioning of policy mixes and the means and methods by which they may be enhanced.

Many environmental policies fall into this latter category of both high horizontality and high verticality and the article assessed two cases in this area of policymaking sharing this same characteristic-one considered a success and the other a failure-in order to determine what lessons could be derived from them for the better integration of environmental policy mixes.

The two cases illustrate several key design points. First, they show that the institutional framework developed in the policy design stage is a crucial predictor of success or failure in multilevel, multi-sectoral integrated governance areas, with the ICZM case showing the weaknesses of de-centralized inter-governmental efforts while the GBRMP case illustrates the advantages of the existence of multipurpose special bodies able to cross agency and government jurisdictional boundaries.

Second, they show there is the need to move beyond the use of just 'substantive' tools designed to affect production, consumption and distributive arrangements and to include procedural tools such as public participation and stakeholder funding in policy mixes in order to help integrate existing, and sometimes, rival policy initiatives into a more cohesive strategy (May, Jones, Beem, Neff-Sharum, \& Poague, 2005; Howlett, 2000).

\section{Acknowledgements}

The authors would like to thank the reviewers for their helpful suggestions on how to improve this article.

\section{Conflict of Interests}

The authors declare no conflict of interests.

\section{References}

Anderson, J., Gomez, C. W., McCarney, G., Adamowicz, W., Chalifour, N. J., Weber, M. L., . . . Howlett, M.
(2010). Ecosystem service valuation, market-based instruments, and sustainable forest management: $A$ primer (SSRN Scholarly Paper). Rochester, NY: Social Science Research Network.

Australia's Great Barrier Reef Marine Park Authority. (2014). Abbot point capital dredging project. Retrieved from http://www.gbrmpa.gov.au/about-us/ consultation/current-proposals-completed-assessme nt/abbot-point-capital-dredging-project

Béland, D., \& Wadden, A. (2012). The Obama presidency and health insurance reform: Assessing continuity and change. Social Policy and Society, 11(3),319-330.

Bolleyer, N., \& Borzel, T. A. (2010). Non-hierarchical policy coordination in multilevel systems. European Political Science Review, 2(2), 157-185.

Boonekamp, P. G. M. (2006). Actual interaction effects between policy measures for energy efficiency-A qualitative matrix method and quantitative simulation results for households. Energy, 31(14), 2848-2873.

Braathen, N. A. (2005). Environmental agreements used in combination with other policy instruments. In E. Croci (Ed.), The handbook of environmental voluntary agreements (Vol. 43, pp. 335-364). Dodrecht: Springer.

Braathen, N. A. (2007). Instrument mixes for environmental policy: How many stones should be used to kill a bird? International Review of Environmental and Resource Economics, 1(2), 185-235.

Briassoulis, H. (2004, December). Policy integration for complex policy problems: What, why and how. Paper presented at the 2004 Greening of Policies: Interlinkages and Policy Integration, Berlin, Germany.

Candel, J., \& Biesbroek, R. (2016). Toward a processual understanding of policy integration. Policy Sciences, 49, 211-231.

Carter, P. (2012). Policy as palimpsest. Policy \& Politics, 40(3), 423-443.

Cejudo, G., \& Michel, C. M. (2017). Addressing fragmented government action: Coordination, coherence, and integration. Policy Sciences. Manuscript in preparation.

Chapman, R. (2003). A policy mix for environmentally sustainable development-Learning from the Dutch experience. New Zealand Journal of Environmental Law, $7(1), 29-51$.

Commonwealth of Australia. (2013). Great barrier reef strategic assessment program report, draft for public comment. Townsville: Australian GBRMP Authority.

da Costa Canoquena, J. M. (2013). Reconceptualising policy integration in road safety management. Transport Policy, 25, 61-80.

Day, J. C., \& Dobbs, K. (2013). Effective governance of a large and complex cross-jurisdictional marine protected area: Australia's Great Barrier Reef. Marine Policy, 41, 14-24.

Del Río, P. (2009). Interactions between climate and energy policies: The case of Spain. Climate Policy, 9(2), 119-138. 
Del Río, P. (2010). Analysing the interactions between renewable energy promotion and energy efficiency support schemes: The impact of different instruments and design elements. Energy Policy, 38(9), 4978-4989.

Del Río, P. (2014). On evaluating success in complex policy mixes. Policy Sciences, 47, 267-287.

Doremus, H. (2003). A policy portfolio approach to biodiversity protection on private lands. Environmental Science \& Policy, 6, 217-232.

Elburg-Velinova, D. V., Valverde, C. P., \& Salman, A. (1999). Progress of ICZM in European countries: A pilot study. Leiden: Coastal and Marine Union.

Enderlein, H., Wälti, S., \& Zürn, M. (2011). Handbook on multi-level governance. Cheltenham: Edward Elgar Publishing.

Fernandes, L., Day, J. O. N., Lewis, A., Slegers, S., Kerrigan, B., Breen, D. A. N., . . Stapleton, K. (2005). Establishing representative, no-take areas in the Great Barrier Reef: Large-scale implementation of theory on marine protected areas. Conservation Biology, 19(6), 1733-1744.

Food and Agriculture Organization. (1995). Code of conduct for responsible fisheries. Rome: Food and Agriculture Organization.

Grabosky, P. (1995). Counterproductive regulation. International Journal of the Sociology of Law, 23, 347-369.

Gunningham, N., Grabosky, P., \& Sinclair, D. (1998). Smart regulation: Designing environmental policy. Oxford: Clarendon Press.

Harvey, N., \& Hilton, M. (2006). Approaches to coastal management in the Asia-Pacific region. In N. Harvey (Ed.), Global change and integrated coastal management: The Asia-Pacific region (pp. 39-66). London: Springer.

Haward, M., \& Vince, J. (2008). Oceans governance in the twenty-first century: Managing the blue planet. Cheltenham: Edward Elgar Publishing.

Hennicke, P. (2004). Scenarios for a robust policy mix: The final report of the German study commission on sustainable energy supply. Energy Policy, 32(15), 1673-1678.

Hooghe, L., \& Marks, G. (2003). Unravelling the central state, but how? Types of multi-level governance. American Political Science Review, 97(2), 233-243.

Hosseus, D., \& Pal, L. A. (1997). Anatomy of a policy area: The case of shipping. Canadian Public Policy, 23(4), 399-416.

Hou, Y., \& Brewer, G. (2010). Substitution and supplementation between co-functional policy instruments: Evidence from state budget stabilization practices. Public Administration Review, 70(6), 914-924.

Howlett, M. (1999). Federalism and public policy. In J. Bickerton \& A. Gagnon (Ed.), Canadian politicsThird edition (pp. 523-539). Peterborough: Broadview Press.

Howlett, M. (2004). Beyond good and evil in policy imple- mentation: Instrument mixes, implementation styles and second generation theories of policy instrument choice. Policy \& Society, 23(2), 1-17.

Howlett, M. (2005). What is a policy instrument? Policy tools, policy mixes and policy implementation styles. In P. Eliadis, M. Hill, \& M. Howlett (Eds.), Designing government: From instruments to governance (pp. 31-50). Montreal: McGill-Queen's University Press.

Howlett, M. (2013). Policy design: What, who, how and why? In P. LeGales (Ed.), Policy Instruments (pp. 1233-1245). Paris: Presses de Sciences Po.

Howlett, M., \& del Río, P. (2015). The parameters of policy portfolios: Verticality and horizontality in design spaces and their consequences for policy mix formulation. Environment and Planning C, 33(5), 12331245.

Howlett, M., \& Mukherjee, I. (2014). Policy design and non-design: Towards a spectrum of policy formulation types. Politics and Governance, 2(2), 57-71.

Howlett, M., Ramesh, M., \& Wu, X. (2015). Understanding the persistence of policy failures: The role of politics, governance and uncertainty. Public Policy and Administration, 30(3/4), 209-220.

Howlett, M., \& Rayner, J. (2004). (Not so) 'smart regulation'? Canadian shellfish aquaculture policy and the evolution of instrument choice for industrial development. Marine Policy, 28(2), 171-184.

Howlett, M., \& Rayner, J. (2007). Design principles for policy mixes: Cohesion and coherence in 'new governance arrangements'. Policy and Society, 26(4), 1-18.

Humphreys, S., \& Burbridge, P. (2003). Sectoral and territorial cooperation in the European demonstration programme on ICZM. Coastal Management, 31, 160.

Janssen, G. (2004). Harmonization of management plans: Natura 2000, water framework directive and EU recommendation on ICZM. Coastline Reports, 2, 251-258.

Jay, S., Flannery, W., Vince, J., Liu, W., Xue, J., Matczak, M., ... Dean, H. (2013). International progress in marine spatial planning. In A. Chircop, S. Coffen-Smout, \& M. Nijhoff (Eds.), Ocean yearbook 27 (pp. 171-212). Leiden: Martinus Nijhof.

Jordan, A., \& Lenschow, A. (2008). Innovation in environmental policy? Integrating the environment for sustainability. Cheltenham: Edward Elgar Publishing Ltd.

Jordan, A., \& Lenschow, A. (2010). Environmental policy integration: A state of the art review. Environmental Policy and Governance, 20(3), 147-158.

Jordan, A., Benson, D., Wurzel, R., \& Zito, A. (2011). Policy instruments in practice. In J. S. Dryzek, R. B. Norgaard, \& D. Schlosberg (Eds.), Oxford handbook of climate change and society (pp. 536-549). Oxford: Oxford University Press.

Jordan, A., Benson, D., Zito, A., \& Wurzel, R. (2012). Environmental policy: Governing by multiple policy instruments? In J. J. Richardson (Ed.), Constructing a policy state? Policy dynamics in the EU (pp. 104-124). Oxford: Oxford University Press. 
Kaiser, A., Kaiser, A., \& Biela, J. (2012). Policy making in multilevel systems: Federalism, decentralisation, and performance in the OECD countries. Colchester: European Consortium for Political Research Press.

Keast, R., Brown, K., \& Mandell, M. (2007). Getting the right mix: Unpacking integration meanings and strategies. International Public Management Journal, 10(1), 9-33.

Kenchington, R. A., \& Day, J. C. (2011). Zoning, a fundamental cornerstone of effective marine spatial planning: Lessons learnt from the Great Barrier Reef, Australia. Journal of Coastal Conservation, 15(2), 271-278.

Kern, F., \& Howlett, M. (2009). Implementing transition management as policy reforms: A case study of the Dutch Energy sector. Policy Sciences, 42(4), 391-408.

Kiss, B., Manchón, C. G., \& Neij, L. (2012). The role of policy instruments in supporting the development of mineral wool insulation in Germany, Sweden and the United Kingdom. Journal of Cleaner Production, 48(1), 187-199.

Leplay, S., \& Thoyer, S. (2011). Synergy effects of international policy instruments to reduce deforestation: A cross-country panel data analysis (Working Paper LAMETA). Montpellier: University of Montpellier.

Levin, K., Cashore, B., Bernstein, S., \& Auld, G. (2012). Overcoming the tragedy of super wicked problems: Constraining our future selves to ameliorate global climate change. Policy Sciences. doi:10.1007/s11077012-9151-0

Macintosh, A., Bonyhady, T., \& Wilkinson, D. (2010). Dealing with interests displaced by marine protected areas: A case study on the great barrier reef marine park structural adjustment package. Ocean \& Coastal Management, 53(9), 581-588.

May, P., Jones, B. D., Beem, B. E., Neff-Sharum, E. A., \& Poague, M. K. (2005). Policy coherence and component-driven policymaking: Arctic policy in Canada and the United States. Policy Studies Journal, 33(1), 37-63.

McKenna, P. (n.d.). Moving towards Integrated Coastal Zone Management: The proposal for a European Parliament and Council recommendation on Integrated Coastal Zone Management management. Retrieved from http://www.mapama.gob.es/imagenes/en/09 0471228000651d_tcm11-28950.pdf

Milkman, K. L., Mazza, M. C., Shu, L. L., Tsay, C., \& Bazerman, M. H. (2012). Policy bundling to overcome loss aversion: A method for improving legislative outcomes. Organizational Behavior and Human Decision Processes, 117(1), 158-167.

Peters, B. G. (1998). Managing horizontal government: The politics of coordination. Ottawa: Canadian Centre for Management Development.

Peters, B. G. (2005). Conclusion: The future of instruments research. In P. Eliadis, M. Hill, \& M. Howlett (Eds.), Designing government: From instruments to governance (pp. 353-363). Montreal: McGillQueen's University Press.
Portman, M. E., Dalton, T. M., \& Wiggin, J. (2015). Revisiting integrated coastal zone management: Is it past its prime? Environment: Science and Policy for Sustainable Development, 57(2), 28-37.

Post, J. C., \& Lundin, C. G. (Eds.). (1996). Guidelines for Integrated Coastal Zone Management. Washington, DC: The World Bank.

Ring, I., \& Schroter-Schlaack, C. (2010). Instrument mixes for biodiversity policies. Leipzig: Helmholtz Centre for Environmental Research.

Sainsbury, K., Haward, M., Kriwoken, L., Tsamenyi, M., \& Ward, T. (1997). Australia's oceans policy: Oceans planning and management, multiple use management in the Australian marine environment: principles, definitions and elements (Issues Paper 1). Canberra: Environment Australia.

Salamon, L. M. (1989). The tools approach: Basic analytics. In L. S. Salamon \& M. S. Lund (Eds.), Beyond privatization: The tools of government action (pp. 23-50). Washington, DC: Urban Institute.

Schneider, A., \& Ingram, H. (1990). Policy design: Elements, premises and strategies. In S. S. Nagel (Ed.), Policy theory and policy evaluation: Concepts, knowledge, causes and norms (pp. 77-102). New York, NY: Greenwood.

Schneider, A., \& Ingram, H. (1993). Social construction of target populations: Implications for politics and policy. American Political Science Review, 87(2), 334-347.

Schneider, A., \& Ingram, H. (1994). Social constructions and policy design: Implications for public administration. Research in Public Administration, 3, 137-173.

Schneider, A., \& Ingram, H. (1997). Policy design for democracy. Lawrence: University Press of Kansas.

Schneider, A., \& Ingram, H. (2005). Deserving and entitled: Social constructions and public policy (SUNY Series in Public Policy). Albany, NY: State University of New York.

Sutton, S. G., \& Tobin, R. C. (2009). Recreational fishers' attitudes towards the 2004 rezoning of the Great Barrier Reef Marine Park. Environmental Conservation, 36(3), 245-252.

Taeihagh, A., Givoni, M., \& Bañares-Alcántara, R. (2013). Which policy first? A network-centric approach for the analysis and ranking of policy measures. Environment and Planning B: Planning and Design, 40(4), 595-616. doi:10.1068/b38058

Thelen, K. (2004). How institutions evolve: The political economy of skills in Germany, Britain, the United States and Japan. Cambridge: Cambridge University Press.

Tietenberg, T., \& Lewis, L. (2008). Environmental \& natural resource economics (8th ed.). Boston: Prentice Hall.

Tinbergen, J. (1952). On the theory of economic policy. Dordrecht: North-Holland Pub. Co.

Trebilcock, M. J., \& Prichard, J. R. S. (1983). Crown corporations: The calculus of instrument choice. In M. J. 
Trebilcock (Ed.), Crown corporations in Canada: The calculus of instrument choice (pp. 1-50). Toronto: Butterworths.

Tupper, A., \& Doern, G. B. (1981). Public corporations and public policy in Canada. In A. Tupper \& G. B. Doern (Eds.), Public corporations and public policy in Canada (pp. 1-50). Montreal: Institute for Research on Public Policy.

Van der Heijden, J. (2011) Institutional layering: A review of the use of the concept. Politics, 31(1), 9-18.

Vince, J. (2013). Marine bioregional plans and implementation issues: Australia's oceans policy process. Marine Policy, 38, 325-329.

Vince, J. (2014). Oceans governance and marine spatial planning in Australia. Australian Journal of Maritime and Ocean Affairs, 6(1), 5-17.

Vince, J. (2015). Integrated policy approaches and policy failure: The case of Australia's Oceans Policy. Policy Sciences, 48(2), 159-180.

Weitzman, M. L. (1974). Prices vs quantities. The Review of Economic Studies, 41, 477-491.

Williams, A. M., \& Balaz, V. (1999). Privatisation in Central Europe: Different legacies, methods and outcomes. Environment and Planning C: Government and Policy, 17, 731-751.

Yi, H., \& Feiock, R. C. (2012). Policy tool interactions and the adoption of state renewable portfolio standards. Review of Policy Research, 29(2), 193-206.

\section{About the Author}
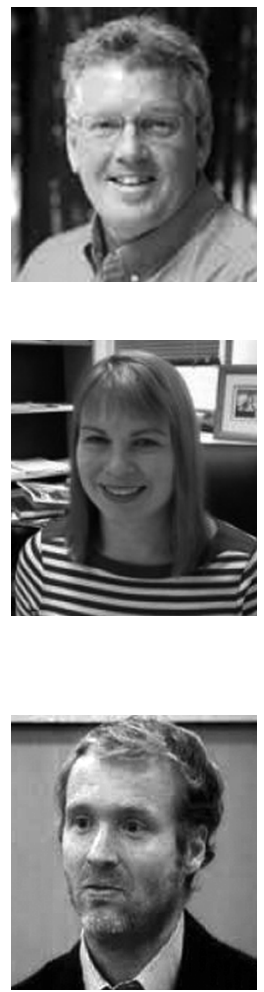

Michael Howlett is Burnaby Mountain Chair in the Department of Political Science at Simon Fraser University and Yong Pung How Chair Professor in the Lee Kuan Yew School of Public Policy at the National University of Singapore. He specializes in public policy analysis, political economy, and resource and environmental policy. His articles have been published in numerous professional journals in Canada, the United States, Europe, Latin America, Asia, and Australia and New Zealand. He is the current chair of Research Committee 30 (Comparative Public Policy) of the International Political Science Association and sits on the organizing committee of the International Conference on Public Policy.

Joanna Vince is a senior lecturer in the Politics and International Relations Program at the School of Social Sciences in the College of Arts and Law. Her area of specialization is oceans governance. Joanna's research aligns to the University's research theme of Marine, Antarctic and Maritime. Her research interests include international and domestic ocean governance with a focus on Australian oceans policy, marine debris (local and global), comparative oceans governance, coastal zone management, and marine protected areas. She is an Editorial Board member of the Australian Journal of Maritime and Ocean Affairs and a member of the Institute of the Study of Social Change and the Centre for Marine Socio-Ecology.

Pablo del Río is head of the Environmental Economics Group and senior (tenured) researcher at the Institute for Public Goods and Policies at the National Research Council of Spain (CSIC). His main areas of research are at the cross-road of Energy Economics, Environmental Economics and Innovation Economics. He holds a PhD in Environmental Economics, a MSc in Economics and Business and a BSc in Law. He has a hundred international publications. 